\title{
Kesadaran (Awareness) dan Pemahaman (Understanding) Akuntan Pendidik terhadap XBRL
}

\author{
Yusti Pujisari ${ }^{1}$, Frasto Biyanto ${ }^{2}$ \\ ${ }^{1}$ STIE Solusi Bisnis Yogyakarta \\ mamafalie@gmail.com \\ ${ }^{2}$ STIE YKPN Yogyakarta \\ frastobiyanto@gmail.com
}

\begin{abstract}
$X B R L$ is a global standard that enables financial information to be analyzedquickly, cheaply, and easily and increases access by users. Since 2015 Indonesia Exchange (IDX) has encouraged companies in Indonesia to adopt XBRL for their financial report. XBRL format made by IDX called IDX Taxonomy 2014. The adoption of XBRL in company financial report finally has an impact to the accounting education. This is because reducing and eliminating the gap between accounting education and accounting practice must always be sought. The purpose of this study is to explore the awareness and understanding of accounting educators in Indonesiaabout XBRL.Accounting educators are the profession which have responsibility in accounting education development. There were 124 accounting educators as a sample from several universities in Indonesia. The questionnaires were used to obtain the data, which distributed via email and social media. The results show that most of accounting educators do not aware and understand about what XBRL is. However, they who have not know about $X B R L$ yet, has a curiosity and want to learn more about XBRL.

Keywords: XBRL, accounting educators, awareness, understanding
\end{abstract}

\section{Abstrak}

XBRL merupakan standar global yang memungkinkan informasi keuangan dianalisis dengan cepat, murah, dan mudah serta meningkatkan aksesnya oleh pengguna. Sejak tahun 2015, Bursa Efek Indonesia telah mendorong perusahaan untuk mengadopsi XBRL dalam pelaporan keuangannya. Format XBRL yang dibuat oleh Bursa Efek Indonesia dikenal dengan IDX taxonomy 2014. Adopsi XBRL dalam pelaporan keuangan pada akhirnya akan memiliki dampak pada dunia pendidikan akuntansi. Hal ini karena pendidikan akuntansi akan selalu berupaya mengurangi dan menghilangkan gap antara dunia pendidikan akuntansi dan praktik yang terjadi. Penelitian ini bertujuan untuk mengeksplorasi sejauh mana kesadaran dan pemahaman akuntan pendidik di Indonesia mengenai XBRL. Akuntan pendidik adalah profesi yang bertanggung jawab pada perkembangan pendidikan akuntansi. Terdapat 124 akuntan pendidik dari beberapa perguruan tinggi di Indonesia yang dapat diolah sebagai sampel. Kuisioner digunakan untuk memperoleh data, yang didistribusikan melalui email dan sosial media. Hasilnya menunjukkan bahwa sebagai besar akuntan pendidik belum memiliki kesadaran dan pemahaman mengenai XBRL. Meskipun demikian, akuntan pendidik yang belum mengetahui tentang XBRL memiliki keingintahuan dan ingin mempelajari XBRL.

Kata Kunci: XBRL, akuntan pendidik, kesadaran, pemahaman

\section{PENDAHULUAN}

Era teknologi informasi telah masuk ke dalam semua sendi kehidupan manusia terkait hubungan manusia dengan komunitasnya. Terlebih lagi dalam komunitas dunia bisnis. Dunia bisnis berjalan begitu cepat sejak perkembangan teknologi informasi menjadi suatu hal yang pasti.. Teknologi informasi berperan dalam menciptakan inovasi, baik terkait perkembangan produk, inovasi produksi, inovasi pemasaran dan juga tidak ketinggalan dalam hal penilaian kinerja perusahaan yang mencakup pelaporan keuangan maupun non keuangan.

Teknologi informasi sangat diperlukan dalam pelaporan keuangan 
guna menghasilkan laporan yang cepat, akurat, transparan dan mudah dipahami oleh pembaca. Pembaca laporan keuangan dalam hal ini adalah pihakpihak yang berkepentingan (stakeholder) terhadap kegiatan bisnis sebuah organisasi, baik itu pemegang saham, pemerintah, LSM, calon investor, business analyst, auditor dan lainnya.

Internet merupakan teknologi dalam penyediaan informasi yang paling populer di masyarakat saat ini. Untuk mengakses informasi melalui internet dibutuh website. Website merupakan halaman dalam situs informasi yang mudah diakses dengan sangat cepat melalui jaringan internet. Adanya website ini mendorong perusahaan di seluruh dunia untuk mengunggah performa perusahaan baik keuangan dan non keuangan ke dalam website mereka.

Bila satu perusahaan saja memiliki ratusan lembar halaman dalam website, maka bisa dibayangkan berapa milyar halaman website digunakan untuk penyedia informasi perusahaan di seluruh dunia. Oyelere, Laswad, \& Fisher(2003) menguraikan bahwa terdapat beberapa faktor yang mempengaruhi perusahaan dalam mengunggah laporan keuangan di internet. Faktor tersebut adalah ukuran perusahaan, likuiditas perusahaan,, jenis industri, status listing perusahaan, penyebaran kepemilikan perusahaan, dan tingkat leverage. Dalam hal ini Oyerele.et al., (2003) mengatakan bahwa semakin tinggi ukuran perusahaan, likuiditas dan leverage perusahaan, maka semakin cenderung untuk mengungkapkan kinerja (keuangan dan non keuangan) perusahaan di internet. Selanjutnya, semakin perusahaan berada pada jenis industri yang rentan terhadap kritik juga akan menggunakan media internet untuk mengungkap kinerja perusahaannya dan perusahaan yang listing di bursa efek juga lebih cenderung menggunakan internet dalam mempublikasikan kinerjanya.

Setelah teknologi internet mampu mempermudah perusahaan dalam memberikan informasi keuangan dan non keuangan, yang menjadi pertanyaan selanjutnya adalah bagaimana para stakeholder memilah dan mengolah informasi tersebut sesuai dengan kebutuhannya. Tentunya proses memilah informasi yang dibutuhkan menjadi pekerjaan tersendiri bagi pengguna, mengingat bermilyar informasi dapat diperoleh dengan begitu cepat dan mudah.

Sejauh mana kompleksitas seorang pengguna laporan keuangan dalam mengolah informasi perusahaan yang tersedia di website atau halaman web perusahaan, digambarkan oleh Debreceny \& Gray (2001). Dalam tulisannya, mereka memberikan contoh pekerjaan seorang analis terkait mengolah informasi perusahaan yang tersaji dalam halaman web dan terhubung jaringan internet. Seorang analis sesungguhnya memiliki dua jenis pekerjaan, yaitu mechanics dan analyst. Mechanics terkait dengan pekerjaan pendahuluan yang dilakukan analis, yaitu menempatkan (locating), mengumpulkan (collecting), memilah (disaggregating), menggabung (aggregating) dan memformat (formatting) data. Jika tindakan mechanics ini sudah dilakukan. Selanjutnya, setelah pekerjaan mechanics selesai, seorang analyst akan melakukan pekerjaan analyst nya, yaitu menganalisis data dalam proses mechanics tadi. Jika waktu seorang analis terbatas, maka bisa jadi seorang analyst akan mengalokasikan waktu 
untuk pekerjaan mechanics lebih besar daripada waktu untuk melakukan pekerjaan analisis itu sendiri. Lebih lanjut Debreceny \& Gray, (2001) juga menyinggung adanya pihak ketiga untuk pekerjaan mechanics ini, dan pihak ketiga tersebut tentunya akan mendapatkan fee dari pekerjaan mechanics yang dilakukannya.

Pada perkembangan teknologi, proses pengambilan data melalui halaman web mulai ditunjang dengan perangkat yang disebut intelligent software agents. Seorang analis menggunakan inteligent software agents untuk melakukan pekerjaan mechanics. Namun, perangkat intelligent software agents memiliki kelemahan, seperti yang diuraikan oleh Debreceny \& Gray(2001), bahwa intelligent software agents tidak memiliki metode standar dalam mengidentifikasi halaman web, tidak memiliki standar dalam identifikasi laporan keuangan, dan tidak memiliki elemen pelaporan dan terminologi yang standar untuk mengidentifikasi makna dari elemen laporan keuangan.

Pada tahun 1998 seseorang bernama Charles F. Hoffman yang merupakan anggota AICPA (American Institute of Certified Public Accountant) menemukan gagasan perancangan terkait laporan keuangan yang yang diberi nama XFRML (eXtensible Financial Reporting Markup Language). Namun selanjutnya berganti nama menjadi XBRL (eXtensible Business Reporting Language) pada tahun 2000.

Hoffman dalam wawancara yang dilakukan Tie (2005) mengatakan bahwa XBRL yang merupakan intelligent software tools, merupakan hal fundamental untuk mengkomunikasikan informasi perusahaan dan XBRL telah mengubah cara bagaimana informasi perusahaan disajikan dan dianalisis. XBRL meminimalkan intervensi manual, karena sifat XBRL yang mengubah kelompok teks yang tidak terstruktur menjadi terstruktur.

Dari waktu ke waktu sejak dicetuskan tahun 1998, banyak perusahaan dari negara di dunia telah mengadopsi XBRL. Sebagai contoh Afrika Selatan telah melakukan peluncuran XBRL pada Juli 2006 (Nel \& Steenkamp, 2011), bahkan, Di Amerika Serikat pada tahun 2005 telah dibuat regulasi yang mewajibkan CPA di pemerintahan atau siapapun yang berurusan dengan regulator, untuk mengajukan ringkasan triwulan-an tentang kondisi keuangan dalam format XBRL yang disediakan secara gratis dan dapat diakses di internet.

Kelebihan XBRL dalam hal penyajian dan analisisnya, menjadikan XBRL sebagai hal yang tidak dapat diabaikan oleh perusahaan. Tie(2005) mengatakan bahwa XBRL merupakan standar global yang memungkinkan informasi keuangan dan analisis yang dilakukan menjadi cepat, murah dan mudah serta meningkatkan akses terhadap informasi yang terkadang sulit ditemukan dalam seperangkat data keuangan.Dikatakan bahwa XBRL adalah bahasa untuk komunikasi bisnis dan data keuangan elektronik yang merevolusi pelaporan bisnis di seluruh dunia. (Nel \& Steenkamp, 2011)mengatakan bahwa XBRL membuat informasi keuangan real-time karena data sudah dapat dimengerti oleh komputer dan dengan mudah dapat diubah menjadi laporan keuangan. Lebih lanjut, Steenkamp (2008) menjelaskan bahwa dengan XBRL maka terjadi penghematan waktu dan biaya dalam 
audit dan hal ini tentunya akan lebih banyak layanan bernilai tambah bagi klien.

Stakeholder akan dimudahkan dalam proses memahami sebuah informasi yang disajikan perusahaan. Artinya bahwa, adopsi XBRL oleh perusahaan memiliki nilai tersendiri dalam meningkatkan capital market perusahaan. Penelitian Pinsker dan Li (2008) telah menunjukkan bahwa alasan perusahaan di negara Amerika untuk mengadopsi XBRL adalah agar mereka dapat menjadi leader dalam equity market mereka. Sementara Pinsker dan Li (2008) dalam survey nya pada perusahaan di Kanada, Jerman dan Afrika Selatan menunjukkan bahwa alasan perusahaan di tiga negara tersebut dalam adopsi XBRL adalah lebih pada efisiensi dengan menekan pada biaya operasi (operating cost).

Tie (2005) mengatakan bahwa XBRl merupakan standar global baru dalam memformat informasi keuangan, membuat proses pelaporan dan analisis menjadi lebih cepat, lebih murah dan secara signifikan lebih mudah. Manfaat utama dari XBRL adalah kemudahan pengguna dalam menginteraksikan antar data dan melakukan penelusuran secara mendalam (Gomaa, Markelevich, \& Shaw, 2011). Cohen (2009) menambahkan hal tersebut dapat dilakukan sampai pada fase transaksi, oleh karena itu XBRL diharapkan dapat memudahkan proses pengungkapan dan penyebaran informasi kepada pengguna dan regulator (Baldwin, Brown, \& Trinkle, 2006).

Meskipun memiliki banyak keunggulan, XBRL tidak menyebar dengan cepat di beberapa negara. David(2016) yang melakukan penelitian di New Zealand mengatakan bahwa meskipun dunia internasional menyebarkan adopsi XBRL di seluruh dunia, namun perkembangan adopsi XBRL pada perusahaan-perusahaan di New Zealand tidak terjadi. Hal ini disebabkan tidak adanya keharusan yang ditetapkan oleh pemerintah New Zealand dalam mengadopsi XBRL dan sampai saat ini, baik pemerintah maupun perusahaan swasta tidak mengadopsi XBRL.

Di Indonesia, XBRL baru mulai disosialisasikan sejak Bursa Efek Indonesia (BEI) telah membuat taxonomi yang mengikuti juridiksi XII Direct member yang telah selesai dan mulai disosialisasikan pada tahun 2014 pada perusahaan-perusahaan di Indonesia khususnya perusahaan yang listing di BEI. Selain BEI, Bank Indonesia juga telah menjadi anggota XBRL internasional. Tentunya hal ini menunjukkan bahwa adopsi XBRL di Indonesia cukup tertinggal dari Amerika Serikat yang sudah mewajibkan bagi CPA di pemerintahan ataupun perusahaan yang terkait dengan regulator untuk membuat laporan keuangan XBRL sejak regulasi ditetapkan tahun 2005.

Sosialisasi XBRL yang dilakukan oleh Bursa Efek Indonesia sudah barang tentu menjadi tugas para akuntan untuk mampu memahami laporan keuangan berbasis XBRL. Akuntan terlahir dari institusi pendidikan akuntansi mulai dari jenjang sarjana, master hingga program doktor. Ditambah lagi dengan berbagai sertifikasi bagi para akuntan, baik akuntan yang bergerak di sektor publik (departemen keuangan, BPK, pajak), akuntan perusahaan dan auditor. Sehingga, para akuntan diharapkan telah memiliki kesadaran dan juga keahlian terkait XBRL sejak mereka belajar di perguruan tinggi 
seiring dengan sosialisasi pengadopsian XBRL di dunia kerja.

Pengenalan di perguruan tinggi mengenai adopsi XBRL ditujukan agar tidak terjadi gap antara dunia pendidikan dan dunia kerja. Perlu ada suatu tindakan khusus bagi para akuntan pendidik untuk menghadapi dunia yang berubah terus menerus ini (Chambers, 1966; Staubus, 1975). Kesenjangan antara praktik dengan pendidikan akuntansi telah lama diidentifikasi. Dalam laporan yang disusun oleh American Accounting Association (American Accounting Association, 1986) tentang pendidikan akuntansi AS berisi sebuah pernyataan yang meyakini adanya kesenjangan yang berbeda antara pendidikan dan praktik yang pertama terkait dengan pembelajaran teknik teknik akuntansi tradisional, dan yang terakhir membutuhkan pendekatan dan pengetahuan yang jauh lebih liberal daripada yang saat ini disediakan dalam program pendidikan akuntansi.

Apakah hal tersebut juga terjadi di Indonesia? Sehingga selanjutnya muncul pertanyaan sejauh manakah tingkat kesadaran dan pengetahuan XBRL bagi akuntan pendidik di Indonesia.

Penelitian ini bertujuan untuk mengetahui tingkat kesadaran dan pengetahuan XBRL para akuntan pendidik di Indonesia.. Penelitian ini bersifat exploratory mengingat belum banyak penelitian XBRL yang dilakukan di Indonesia.

\section{KAJIAN TEORI}

XBRL merupakan sebuah format pelaporan, lebih tepatnya standar format pelaporan terbuka yang memungkinkan dilakukan otomasi pembagian informasi bisnis global yang berisi buku besar perusahaan, laporan laba rugi, arus kas, neraca, catatan atas laporan keuangan dan persyaratan lain dalam pelaporan keuangan bisnis (Kernan, 2008).

Pinsker \& Li (2008) meneliti adopsi XBRL di Kanada, Jerman, Afrika Selatan dan Amerika Serikat. Diambil 4 negara tersebut karena dianggap sebagai "early adopter" laporan keuangan XBRL. Penelitian dilakukan dengan wawancara melalui telepon atau email. Wawancara dilakukan untuk membantu para eksekutif perusahaan dan manajer informasi keuangan memiliki pemahaman yang lebih baik mengenai adopsi XBRL. Hasil wawancara menunjukkan bahwa di 3 negara (kecuali Amerika Serikat) mengatakan bahwa keuntungan adopsi XBRL adalah terjadinya cost saving. Contoh salah satu responden mengatakan bahwa bentuk cost saving adalah terjadinya peningkatan kemampuan pemrosesan dan pengurangan pada data redundancy.

Responden lain mengatakan bahwa bentuk cost saving yang terjadi adalah pengurangan biaya bookkeeping dan terjadinya efisiensi karena data redundancy pula. 30\% karyawan bookkeeping berkurang dan berpindah ke bagian analis. Selain itu, bentuk lain dalam cost saving adalah waktu yang dibutuhkan untuk membuat laporan keuangan berkurang dari lima atau enam hari per laporan menjadi 15 menit atau bahkan kurang. Selanjutnya, responden beranggapan bahwa biaya yang rendah juga diyakini menurunkan resiko yang dirasakan dari keputusan penyedia modal oleh capital providers. Sementara temuan wawancara di Amerika menunjukkan hasil yang berbeda dengan Jerman, kanada dan Afrika Selatan. Di Amerika Serikat lebih menjadikan adopsi XBRL sebagai tujuan marketing, yaitu 
menarik investor potensial. Sehingga penelitian ini mengindikasikan bahwa perusahaan di Amerika Serikat akan mengadopsi sesuatu dalam hal ini XBRL, bila XBRL mampu menempatkan posisi mereka sebagai leader dalam equity market.

Temuan lain dari penelitian Pinsker, et al (2008) yaitu bahwa di Amerika Serikat, Jerman dan Kanada meyakini bahwa adopsi XBRL memberikan keuntungan kompetitif dibandingkan pesaing mereka yang tidak mengadopsi XBRL, khususnya dalam capital market. Sementara perusahaan di Afika Selatan mengadopsi XBRL untuk membantu dalam mematuhi peraturan perundang-undangan domestik yang akan datang. Selanjutnya, mengenai transparansi, semua responden meyakini bahwa transparansi dapat diperoleh dari adopsi XBRL. Dengan transparansi, akan mengurangi ketidakpastian dan risiko dalam modal yang disediakan untuk perusahaan dan juga mengurangi cost of capital.

Venkatesh \& Armitage(2012) melakukan survei online untuk mengetahui tingkat pengetahuan (knowledge) dan kesadaran (awareness) mengenai XBRL serta ingin mengetahui persepsi responden mengenai pentingnya memberikan jaminan atau kepastian (assurance) dan tingkatan kepastian yang dibutuhkan. Responden dalam penelitiannya adalah akuntan dan auditor. Survei dilakukan pada Desember 2009 sampai 2010. Hasilnya menunjukkan bahwa akuntan dan auditor percaya bahwa kepastian dalam laporan keuangan XBRL adalah penting dan akan meningkatkan akurasi dan reliabilitas XBRL tagged financial statements. Responden juga memeringkat tingkat assurance dimulai dari yang paling penting yaitu akurasi, kelengkapan, existence, proper taxonomies, proper extensions, valid extesions dan validity and wellformedness.

Ilias et al (2014) meneliti tingkat kesadaran (awareness) dan keinginan untuk mengadopsi (intention to adopt) XBRL di Malaysia. Survei dilakukan dengan melakukan semi structured interview dan juga kuesioner. Responden penelitian adalah semua pengguna laporan keuangan seperti akuntan, auditor, senior management, konsultan, praktisi pajak, banker, regulator, akademisi dan lain-lain. Sementara responden tersebut berasal dari perusahaan terbuka, perusahaan tertutup, kantor akuntan publik, perusahaan pajak dan lain-lain. Penelitian ini adalah penelitian exploratory mengingat XBRL masih pada tahap awal di Malaysia. Hasil penelitian Ilias et al (2014) menunjukkan bahwa kebanyakan responden belum menyadari mengenai XBRL. Meskipun sebagian besar belum mengetahui mengenai XBRL, namun sebanyak $54,8 \%$ yang tidak mengetahui konsep XBRL, kemungkinan akan mempelajari XBRL dimasa datang. Studi juga bertujuan untuk mengetahui apakah responden meyakini bahwa organisasinya akan mengadopsi XBRL dimasa datang. Hasil menunjukkan bahwa $72,9 \%$ merasa tidak tahu dan tidak memiliki pemikiran terkait adopsi XBRL dalam perusahaan mereka dan ini menunjukkan bahwa adopsi XBRL hanya dilakukan bila telah ada pemahaman dan kesadaran mengenai XBRL.

David (2016) yang melakukan penelitian di New Zealand mengatakan bahwa meskipun dunia internasional menyebarkan adopsi XBRL di seluruh 
dunia, namun perkembangan adopsi XBRL pada perusahaan-perusahaan di New Zealand tidak terjadi. Hal ini disebabkan tidak adanya keharusan yang ditetapkan oleh pemerintah New Zealand dalam mengadopsi XBRL dan sampai saat ini, baik pemerintah maupun perusahaan swasta tidak mengadopsi XBRL (David, 2016).

\section{Manfaat XBRL}

Ketersediaan informasi saat ini yang sangat banyak membutuhkan kemampuan organisasi/perusahaan maupun individual untuk mampu melakukan proses pemilahan, pengelompokan informasi dan analisis yang tidak memakan waktu lama tetapi tetap akurat. Tie (2005) mengatakan bahwa XBRL merupakan standar global yang memungkinkan informasi keuangan dan analisis yang dilakukan menjadi cepat, murah dan mudah serta meningkatkan akses terhadap informasi yang terkadang sulit ditemukan dalam seperangkat data keuangan. XBRL dikembangkan dari teknologi XML. XML (eXtensible Markup Language) dirancang untuk menyediakan data yang banyak dan dapat diakses oleh sejumlah besar pemakai, khususnya dalam format web browser (Weber, 2003; Pinsker \& Li, 2008).

Dalam situs XBRL disebutkan pihakpihak yang membutuhkan XBRL, yaitu:

1. Regulator keuangan. yang membutuhkan informasi mengenai kinerja yang kompleks dan informasi risiko tentang lembaga yang mereka atur.

2. Regulator sekuritas dan bursa efek yang perlu menganalisis kinerja dan kepatuhan perusahaan dan sekuritas yang terdaftar, dan perlu memastikan bahwa informasi ini tersedia bagi pasar untuk dikonsumsi dan dianalisis.

3. Pendaftar bisnis yang perlu menerima dan menyediakan berbagai data perusahaan tentang perusahaan swasta dan publik, termasuk laporan keuangan tahunan.

4. Otoritas pajak yang membutuhkan laporan keuangan dan informasi kepatuhan lainnya dari perusahaan untuk memproses dan meninjau urusan pajak perusahaan mereka.

5. Otoritas kebijakan moneter dan statistik yang membutuhkan informasi kinerja keuangan dari berbagai organisasi yang berbeda.

6. Perusahaan yang perlu memberikan informasi kepada satu atau lebih dari regulator yang disebutkan di atas.

7. Perusahaan yang perlu secara akurat memindahkan informasi ke dalam kelompok yang kompleks.

8. Rantai pasokan yang perlu bertukar informasi untuk membantu mengelola risiko dan mengukur aktivitas.

9. Instansi pemerintah yang menyederhanakan proses bisnis dan mengurangi birokrasi, baik dengan menyelaraskan definisi data atau mengkonsolidasikan kewajiban pelaporan (atau keduanya).

10. Instansi pemerintah yang meningkatkan pelaporan pemerintah dengan menstandardisasi cara konsolidasi atau laporan transaksional disiapkan dan digunakan dalam lembaga pemerintah dan / atau dipublikasikan ke domain publik.

11. Penyedia data spesialis yang menggunakan kinerja dan informasi risiko yang dipublikasikan ke pasar dan membuat perbandingan, peringkat, dan produk informasi bernilai tambah lainnya untuk pelaku pasar lainnya. 
12. Analis yang perlu memahami risiko dan kinerja relatif.

13. Investor yang perlu membandingkan investasi potensial dan memahami kinerja yang mendasari investasi yang ada.

14. Akuntan menggunakan XBRL untuk mendukung persyaratan pelaporan klien dan sering terlibat dalam persiapan laporan XBRL.

Adapun keuntungan dari XBRL (Bursa Efek Indonesia, 2015) adalah sebagai berikut:

1. Untuk melakukan Analisa Laporan yang lebih baik

2. Penghematan biaya

3. Lebih cepat, akurat dan dapat diandalkan

4. Mengurangi perbandingan yang dilakukan secara manual diantara laporan

5. Mengurangi input ulang data

6. Berguna untuk penyebaran informasi menggunakan internet

7. Standarisasi format pelaporan

\section{METODE PENELITIAN}

Studi ini merupakan studi exploratory dengan tujuan untuk mengetahui pemahaman XBRL dikalangan akuntan pendidik di Indonesia. Target populasi dari survei adalah dosen akuntansi di Indonesia. Survei dilaksanakan dengan mengirimkan pertanyaan survey melalui media online yaitu email, Whatsapp baik secara grup maupun individual, dan Facebook. Survei dibuat dalam bentuk kuesioner. Kuesioner yang digunakan diadopsi dari penelitian Nel \& Steenkamp (2008) dan juga digunakan oleh Ilias et al (2014) yang menggunakan kuesioner tersebut di Malaysia. Pertanyaan kuesioner mencakup kesadaran (awareness), implementasi (implementation), pemahaman (understanding), demand for XBRL knowledge dan intention to use.

Pertanyaan survey disusun menggunakan Google Form yang tautannya dibagikan melalui media online yang telah disebutkan. Jumlah responden yang memberikan tanggapan sebanyak 129 responden. Terdapat 5 tanggapan tidak lengkap, sehingga sebanyak 124 respon yang diolah. Total responden yang menerima kuesioner sebanyak 341 orang, dengan jumlah tanggapan 129, maka diketahui respons rate dari kuesioner adalah $37,8 \%$.

Responden yang memberikan tanggapan berasal dari 50 perguruan tinggi baik negeri maupun swasta, dari 41 kota di Indonesia. Informasi demografis dari responden dosen akuntansi disajikan pada Tabel 1 . Sebagian besar responden berusia 40 50 tahun $(41,2 \%)$, kemudian disusul rentang usia 25-39 tahun $(38,8 \%)$ dan kelompok usia di atas 50 tahun sebanyak 20\%. Dari sisi jenis kelamin mayoritas adalah wanita sebanyak $57,7 \%$. Pendidikan responden minimal S2 (40\%), sedang menempuh pendidikan S3 (32,4\%), dan S3 (27,6\%). Kepangkatan akademik dengan jenjang Asisten Ahli $32 \%$, Lektor $49,7 \%$, Lektor Kepala $17,4 \%$, sisanya Guru Besar $(<1 \%)$.

\section{HASIL DAN PEMBAHASAN}

Respon untuk pertanyaan pertama "Apakah Anda pernah mendengar/mengetahui mengenai eXtensible Business Reporting Language (XBRL)?" mengindikasikan bahwa pengetahuan dosen akuntansi terhadap XBRL sangatlah kurang. Hal tersebut ditunjukkan bahwa hanya 3,2\% (4 orang dari 129) responden yang merasa 
memiliki pengetahuan yang cukup mengenai XBRL. Bahkan sebanyak $34,7 \%$ responden merasa

belum tahu bahkan belum mendengar mengenai XBRL. Sebanyak $37,9 \%$ dari para pengajar tersebut pernah mendengar atau mengetahui mengenai XBRL akan tetapi merasa tidak memiliki pemahaman terhadap XBRL. Hanya $24,2 \%$ responden yang pernah mendengar dan memiliki pengetahuan dasar mengenai XBRL. Perhatikan Gambar 1.

Walaupun pemahaman dosen akuntansi terhadap isu XBRL rendah, sebagaimana diindikasikan pada jawaban pertanyaan 1, akan tetapi minat dosen akuntansi terhadap XBRL sangat tinggi. Hal ini ditunjukkan pada jawaban pada pertanyaan kedua (Grafik 2), yaitu “: Apakah anda memiliki rencana untuk menggali pengetahuan mengenai XBRL di masa yang akan datang?". Sebagian besar dosen (91\%) memiliki rencana untuk mempelajari XBRL di masa yang akan datang, dan hanya $8,9 \%$ yang tidak tertarik untuk mempelajarinya di masa datang $\quad(2,4 \% \quad$ merasa sudah mengetahuinya dan tidak perlu untuk belajar lagi). Menariknya dari $91 \%$ yang berencana mempelajari XBRL 15,4\% nya merasa sudah memiliki pengetahuan tetapi tertarik untuk belajar lebih lanjut (Gambar 2).

Walaupun sebagian besar responden merasa belum memiliki pemahaman yang cukup mengenai XBRL, 62,9\% dari mereka merasa bahwa XBRL perlu dimasukkan dalam kurikulum akuntansi. Terdapat responden yang menyarankan sebagai bentuk praktikum, adapula yang menyarankan sebagai salah satu subjek materi pada matakuliah Sistem Informasi. Para dosen merasa perlu memberikan materi XBRL kepada mahasiswa karena merupakan tuntutan perkembangan jaman dan teknologi yang dapat memberikan bekal bagi lulusan untuk masuk ke dalam praktik akuntansi. Adapun sebanyak 35,5\% responden merasa tidak tahu perlu tidaknya XBRL dimasukkan dalam kurikulum akuntansi karena mereka merasa tidak memiliki pengetahuan mengenai XBRL sehingga tidak dapat memutuskannya. Hanya 2 responden saja yang tidak perlu untuk memasukkan XBRL ke dalam kurikulum akuntansi dengan alasan materi dalam akuntansi sudah terlalu banyak (Gambar 3). Menariknya sebanyak 12,9\% responden menjawab bahwa perguruan tingginya telah memperkenalkan XBRL dalam proses pembelajaran akuntansi di perguruan tingginya, sedangkan $87,1 \%$ nya belum ada materi yang mengenalkan XBRL.

Pengajar Akuntansi juga menunjukkan minat pada pemanfaatan XBRL untuk pengambilan keputusan dan penelitian di masa yang akan datang. Hal ini ditunjukkan pada jawaban persetujuan pernyataan berikut:"Saya berkeinginan menggunakan XBRL di masa yang datang". Sebanyak 12,9\% menyatakan sangat setuju, dan $54,8 \%$ menyatakan setuju. Adapun 26,6\% menyatakan tidak tahu karena belum memiliki pengetahuan mengenai XBRL, sisanya menyatakan ketidak setujuan dan sangat tidak setuju. Sehingga dari jawaban tersebut dapat ditarik dugaan kuat bahwa sebagian besar responden memiliki keinginan untuk menggunakan XBRL (Gambar 4).

Sebanyak $16,9 \%$ menyatakan sangat setuju dan $51,6 \%$ menyatakan setuju dengan pernyataan "Saya berkeinginan menggunakan XBRL untuk menghasilkan informasi keuangan yang 
bermanfaat untuk pengambilan menggunakan XBRL sebagai sumber keputusan". Hanya 4\% yang menyatakan data untuk penelitian di masa yang akan kurang setuju, dan tidak ada yang datang. Terdapat $15,3 \%$ yang menyatakan tidak setuju, sebanyak menyatakan sangat setuju dan 50\% 27,4\% menyatakan tidak tahu. Para setuju, sedangkan 29\% merasa tidak tahu responden juga menunjukkan minat (Gambar 5).

Tabel 1. Data Demografis Responden

\begin{tabular}{lr}
\hline Keterangan & Kolom 2 \\
\hline Usia Responden: & $38,8 \%$ \\
25-39 tahun & $41,2 \%$ \\
$40-50$ tahun & $20 \%$ \\
> 5 tahun & \\
& \\
Jenis Kelamin: & \\
Pria & $42,3 \%$ \\
Wanita & $57,7 \%$ \\
Pendidikani: & \\
S1 & \\
Sedang kuliah S2 & $0 \%$ \\
S2 & $0 \%$ \\
Sedang kuliah S3 & $40 \%$ \\
S3 & $32,4 \%$ \\
& $27,6 \%$ \\
Kepangkatan Akademik: & $32 \%$ \\
Asisten Ahli & $49,7 \%$ \\
Lektor & $17,4 \%$ \\
Lektor Kepala & $<1 \%$ \\
Guru Besar & \\
& \\
\hline
\end{tabular}




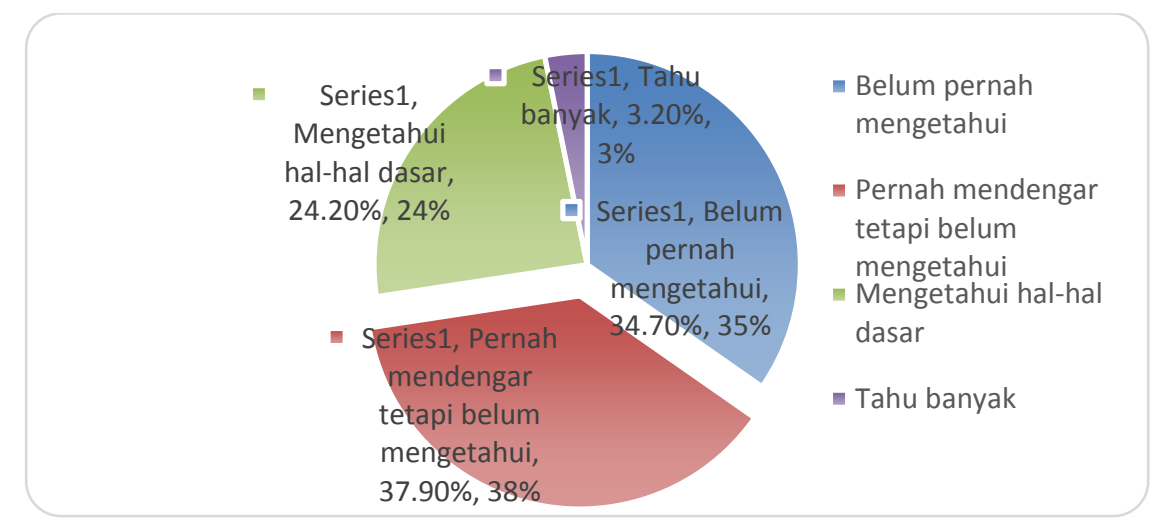

\section{Gambar 1}

Pertanyaan: Apakah Anda pernah mendengar/mengetahui mengenai eXtensible Business Reporting Language (XBRL)?

\begin{tabular}{|c|c|c|}
\hline $\begin{array}{cc}\text { - Series1, Sudah } \\
\text { tahu dan tertarik }\end{array}$ & $\begin{array}{l}\text { Series1, } \\
\text { Sudah } \\
\text { tahu dan } \\
\text { tidak } \\
\text { tertarik,... }\end{array}$ & $\begin{array}{l}\text { Series1, Tidak } \\
\text { tahu dan } \\
\text { tidak tertarik, } \\
6.50 \%, 7 \%\end{array}$ \\
\hline $\begin{array}{l}\text { - Sudah tahu dan } \\
\text { tidak tertarik }\end{array}$ & & \\
\hline $\begin{array}{l}\text { Tidak tahu dan } \\
\text { tertarik untuk } \\
\text { mencari tahu }\end{array}$ & \multicolumn{2}{|c|}{$\begin{array}{c}\text { Series1, Tidak } \\
\text { tahu dan tertarik } \\
\text { untuk mencari } \\
\text { tahu, } 75.60 \% \text {, }\end{array}$} \\
\hline
\end{tabular}

\section{Gambar 2}

Pertanyaan: Apakah anda memiliki rencana untuk menggali pengetahuan mengenai XBRL di masa yang akan datang?

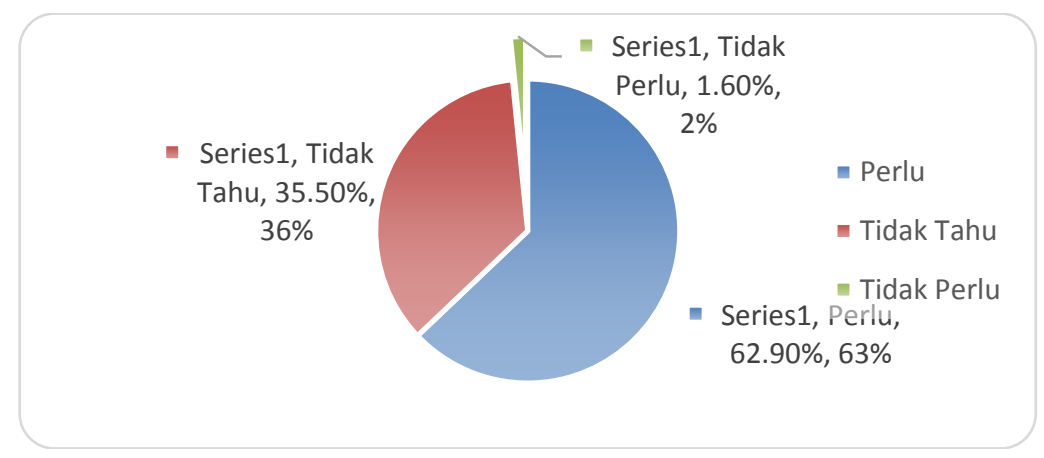

Gambar 3

Pertanyaan: Perlu tidaknya XBRL dimasukkan ke dalam kurikulum Akuntansi 


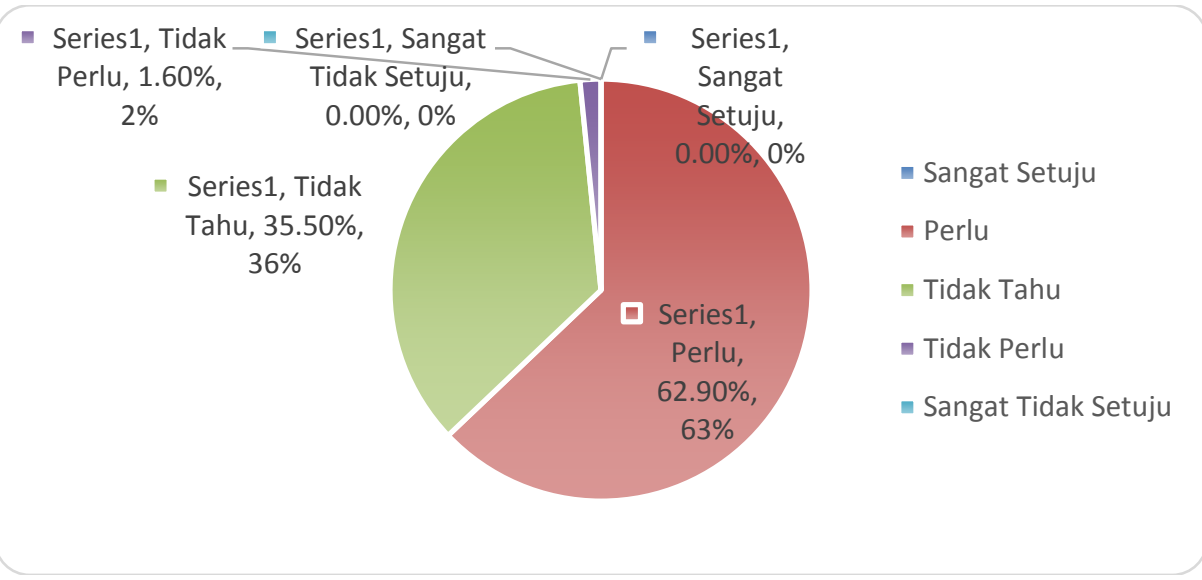

Gambar 4

Pertanyaan: "Saya berkeinginan menggunakan XBRL di masa yang datang"

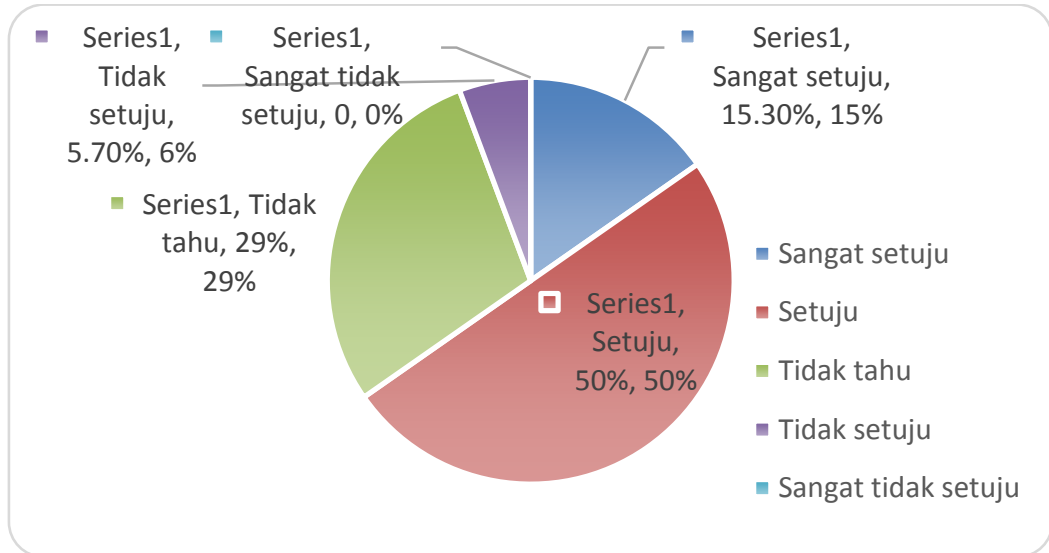

Gambar 5

Pertanyaan:"Keinginan menggunakan XBRL untuk sumber data penelitian di masa yang akan datang"

\section{KESIMPULAN DAN SARAN}

Penelitian ini mengeksplorasi persepsi dari dosen akuntansi mengenai pemahaman mereka terhadap kewajiban penggunaan format XBRL dalam pelaporan keuangan. Secara umum para dosen ini mengindikasikan bahwa pemahaman mereka masih sangat rendah terhadap topik XBRL, walaupun begitu mereka menunjukkan minat yang tinggi untuk mempelajari topik ini dan menggunakannya dalam penelitian yang akan dilakukan di kemudian hari. Para responden juga berpendapat bahwa XBRL merupakan topik penting untuk dimasukkan dalam kurikulum akuntansi sebagai bekal pengetahuan bagi lulusan yang dituntut oleh perkembangan teknologi.

Sebagaimana penelitian yang menggunakan pilihan jawaban terstruktur dan skala Likert pada umumnya, penelitian ini memiliki keterbatasan bias potential self selection sebagai akibat 
perbedaan dalam memahami pembobotan pada setiap pilihan jawaban yang ada. Hal ini dan beberapa faktor lain dapat menyebabkan munculnya nonrespon bias.

Temuan dari penelitian ini diharapkan akan bermanfaat bagi beberapa pihak, pertama pihak regulator, dalam hal ini Bursa Efek Indonesia dan Ikatan Akuntan Indonesia, temuan bahwa tingginya tingkat dosen akuntansi yang belum memahami XBRL menunjukkan bahwa sosialisasi mengenai XBRL masih sangat kurang. Mengingat bahwa format pelaporan menggunakan XBRL sudah diwajibkan oleh BEI sejak tahun 2015 dan sampai pada saat penelitian ini dilaksanakan angka ketidaktahuan responden masih sangat tinggi. Antara praktisi, peneliti, dan akuntan pendidik perlu suatu kerjasama yang akan menjadikan akuntansi akan dapat bertahan dan memenuhiharapan dari penggunanya (Lee, 1989). Kedua, bagi dosen dan peneliti hasil temuan penelitian ini diharapkan dapat digunakan sebagai acuan pada penelitian-penelitian mengenai implementasi XBRL di Indonesia selanjutnya. Masih rendahnya pengetahuan mengenai XBRL di Indonesia memberikan banyak peluang untuk diteliti dan menuntut adanya penyebaran subjek XBRL ini dikalangan mahasiswa sebagai calon praktisi akuntansi di masa yang akan datang.

\section{DAFTAR PUSTAKA}

American Accounting Association. (1986). Committee on the Future Structure, Content, and Scope of Accounting Education, 'Future Accounting Education: Preparing for the Expanding Profession.' AAA.
Baldwin, A. A., Brown, C. E., \& Trinkle, B. S. (2006). XBRL: An impacts framework and research challenge. Journal of Emerging Technologies in Accounting, 3(1), 97-116.

Retrieved from https://www.aaajournals.org/doi/abs /10.2308/jeta.2006.3.1.97

Bursa Efek Indonesia. (2015). XBRL. Retrieved February 24, 2019, from https://www.idx.co.id/perusahaantercatat/xbrl/

Chambers, R. J. (1966). Accounting, Evaluation and Economic Behavior. Prentice Hall.

Cohen, E. E. (2009). XBRL's global ledger framework: Exploring the standardised missing link to ERP integration. International Journal of Disclosure and Governance, 6(3), 188-206. http://doi.org/10.1057/jdg.2009.5

David, J. (2016). The Non-Adoption of XBRL by Professional and Government Organisations in New Zealand and its Implications for Stakeholders. School of Accounting and Commercial Law · Te Kura Kaute, Ture Tauhokohoko. Retrieved from http://researcharchive.vuw.ac.nz/ha ndle/10063/5459

Debreceny, R., \& Gray, G. L. (2001). The production and use of semantically rich accounting reports on the Internet: XML and XBRL. International Journal of Accounting Information Systems, 2(1), 47-74. http://doi.org/10.1016/S14670895(00)00012-9

Gomaa, M. I., Markelevich, A., \& Shaw, L. (2011). Introducing XBRL through a financial statement analysis project. Journal of Accounting Education, 29(2-3), 
153-173.

http://doi.org/10.1016/j.jaccedu.201 1.12 .001

Kernan, K. (2008). XBRL Around the World. Journal of Accountancy, 206(4), 62-66. Retrieved from https://search.proquest.com/openvie $\mathrm{w} / 1 \mathrm{a} 4083 \mathrm{bb} 45 \mathrm{f} 6 \mathrm{fdd} 2 \mathrm{~b} 2 \mathrm{db} 010 \mathrm{~d} 80 \mathrm{c} 6$ 4556/1?pqorigsite $=$ gscholar $\& \mathrm{cbl}=41065$

Lee, T. (1989). Education, Practice and Research in Accounting: Gaps, Closed Loops, Bridges and Magic Accounting. Accounting and Business Research, 19(75), 237253.

http://doi.org/10.1080/00014788.19 89.9728854

Nel, G. F., \& Steenkamp, L. P. (2011). An exploratory study of chartered accountants' awareness and understanding of XBRL. Meditari Accountancy Research, 16(1), 7993.

http://doi.org/10.1108/10222529200 800005

Oyelere, P., Laswad, F., \& Fisher, R. (2003). Determinants of internet financial reporting by New Zealand Companies. Journal of

International Financial Management and Accounting, 14(1), 26-63.

http://doi.org/10.1111/1467646X.00089

Pinsker, R., \& Li, S. (2008, March). Cost and benefit of XBRL Adoption: Early evidence. Communications of the ACM, 48-50. Retrieved from https://www.researchgate.net/profile /Shaomin_Li2/publication/2204250 24_Li_S_Costs_and_benefits_of_X BRL_adoption_early_evidence_Co mmun_ACM_513_4750/links/54563fb40cf26d5090a95ce 2.pdf

Staubus, G. J. (1975). The Responsibility of Accounting Teachers. The Accounting Review, 50(1), 160-175.

Tie, R. (2005, August). XBRL: Its unstopable. Journal of Accountancy, 200(2), 32-35. Retrieved from https://search.proquest.com/openvie w/771d79e79bf6b044bbf25a85d054 8807/1?pqorigsite $=$ gscholar $\& \mathrm{cbl}=41065$

Venkatesh, R., \& Armitage, J. (2012). Accountants' awareness and perceptions about assurance on xbrl financial statements. Journal of Applied Business Research, 28(2), 145-154.

Weber, M. (2003). XML, XBRL, and the Future of Business and Business Reporting. In S. J. Roohani (Ed.), Trust and Data Assurances in Capital Markets: The Role of Technology Solution (1st ed., pp. 36). Pricewaterhouse Coopers. 